\title{
DKK3 wt Allele
}

National Cancer Institute

\section{Source}

National Cancer Institute. DKK3 wt Allele. NCI Thesaurus. Code C95420.

Human DKK3 wild-type allele is located in the vicinity of $11 \mathrm{p} 15.2$ and is approximately 46

$\mathrm{kb}$ in length. This allele, which encodes dickkopf-related protein 3 , is involved in the

modulation of both morphogenesis and intercellular communication. 